The Society for HeAlthcare Epidemiology of America

\begin{tabular}{|c|c|c|c|}
\hline PREsident & John M. Boyce, MD & Past President & Elias Abrutyn, MD \\
\hline President-Elect & Dale N. Gerding, MD & ACADEMIC COUNCILOR & Leonard Mermel, DO, SCM \\
\hline Vice President & William Jarvis, MD & ACADEMIC COUNCILOR & Julie L. Gerberding, MD, MPH \\
\hline TREASURER & Loreen A. Herwaldt, MD & Practice Councilor & Donald R. Graham, MD \\
\hline SECRETARY & Larry J. Strausbaugh, MD & Practice Counchor & Barbara Wade, MD \\
\hline
\end{tabular}

\title{
ICHE on CD-ROM
}

Get rid of office dust, create space for things besides old paper, and still be able to access the past 11 years of ICHE easily by getting ICHE on CD-ROM. It's
PC- and Mac-compatible. Annual updates will be available. Prices start at $\$ 147$. For information, call $1-800-257-8290$ or fax (609) 853-5991.

\section{Liaison Committee}

Due to other commitments to SHEA, Dale Gerding, MD, has resigned as Chair of the Liaison Committee. At present, the committee serves in an ad hoc manner, dealing with issues as they arise. SHEA will reexamine the purpose of the liaisons and what the society expects of them.

\section{Hand-Hygiene Task Force}

HICPAC is considering publishing a hand-hygiene position paper, collaborating with SHEA, APIC, IDSA, and Prevention
Epicenters. A strategic planning session will be organized in May.

\section{Asia Pacific Society of Infection Control}

The Asia Pacific Society of Infection Control is organizing its first international conference (see calendar). A number of SHEA members will speak at the meeting,

\section{Meetings and Courses}

The Seventh Conference on Distance Learning in Public Health, "Networking for the 21st Century," will be held on June 30 July 2, 1999, in Bellevue, Washington. Contact Andrew MacCachran at the Association of Schools of Public Health in Washington, DC (ahm@asph.org).

There's still time to register for the course "Sterilization, Disinfection, and and Julie L. Gerberding, MD, MPH, will serve as SHEA's official delegate to the conference.

\section{Calendar}

May 1-4. SHEA/CDC Training Course in Hospital Epidemiology, Philadelphia, PA. Contact: SHEA (609) 423-7222.

May 19-21. European Society for Pediatric Infectious Diseases 17th Annual Meeting, Heraklion, Crete, Greece. Contact: http://www. upatras.gr/conferences/espid99.

May 30-June 3. 99th ASM

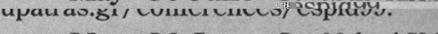

May 30-June 3. 99th ASM General Meeting, Chicago, IL. Contact: meetingsinfo@asmusa.org.

June 6-10. Sixth Conference of the International Society of Travel Medicine, Montreal, Quebec, Canada. Contact: info@eventsintl.com.

June 30-July 2. Networking for the 21st Century, Seventh Conference on Distance Learning in Public Health, Bellevue, WA. Contact: brnbaum@interchange.ubc.ca.

July 4-7. 21st International Congress of Chemotherapy, Birming-

July 4-7. 21st International Congress of Chemotherapy, Birmingham, UK. Contact: 21sticc@gardinercaldwell.com.

August 9-11. First International Congress of the Asia Pacific Society of Infection Control Hono Kono Contact.

\section{Spotted the Site?}

At http://www.apic.org/ajic, full-text articles and abstracts from the 1998 and 1999 issues of the American Journal of Infection Control, plus tables of contents and abstracts from 1996 and 1997, are available online for a limited time. 